\title{
Climate Change Litigation in China: Barriers and Pathways
}

\author{
Si cheng $\mathrm{Wu}^{1}$ \\ ${ }^{1}$ School of law, Sichuan university, Chengdu Sichuan, 610000, China
}

\begin{abstract}
China has been known for its government-oriented method in tackling climate issues, yet the role played by Chinese judiciary in its national response to climate change remains obscure. This article fills the gaps by focusing on the following sub-questions:1) what are the legal barriers and favorable preconditions for the emergence of CCL in China?; 2) if CCL were to occur, what would be the most likely pathway ? An analysis of Chinese legal preconditions reveals that, while some normative and institutional barriers stand in the way, some preconditions have already been satisfied or in the process of preparing. Having compared the preparation of legal preconditions for possible patterns of Chinese CCLs and the motivation of potential plaintiffs, the article concludes that the most likely pattern for Chinese future CCL would be civil actions brought by the NGOs holding the polluters accountable for causing damages to the climate related public interests.
\end{abstract}

\section{Introduction}

According to the Climate Change Litigation Database created by Sabin Center for Climate Change Law, till 2018, 1154 lawsuits over climate change have been brought in 30 jurisdictions, as well as in international tribunals. In the United States alone, 888 cases have been filed as a response to the lack of political action.

These CCLs are meant to fill the gaps left by legislative and regulatory inaction on climate change mitigation and adaptation. Yet, not a single case has been filed in China till now. What are the legal barriers as well as the favorable preconditions for the emergence of CCL in the context of China? If CCL were to occur, what would be the most likely pattern for future potential CCL in China?

To start to answer to these questions, the article is structured as follows. On the basis of the narrow definition of CCL, section 1 outlines the legal threshold issues that are overcome by most successful CCL cases in global context.

Section 2 evaluates the preparation of relevant legal preconditions for the emergence of CCL in China. The existing legal preconditions, the normative and institutional obstacles as well as the legal preconditions in the process of being prepared for both administrative and civil CCL will all be examined and discussed in detail. The timing for this analysis is particularly appropriate given the strong motivation of the government to promote "ecological civilization" in China and recent institutional reforms in the distribution of environmental administrative competences.

In the last part, the article suggests four potential patterns for the future CCL in China (prosecutors vs.

1962446015@qq.com government, NGO vs. industry, prosecutors vs. industry, local government vs. industry) and evaluates the probability of each pattern through a comparison of the motivation of potential plaintiffs (local government, prosecutor and NGO) and the preparation of relevant legal preconditions. Considering the strongest motivation of NGOs and the legal viability for civil CCL in China, the article concludes that the most promising pattern would be CCL brought by NGOs against the GHG emitters.

\section{General legal preconditions for global CCL}

Before entering the intriguing and often complex context of China, it would be useful to look into the global paradigm of CCL and to explore the legal thresholds and challenges often faced the potential litigants. An analysis of the general legal preconditions for global CCL sets the scene for the further discussion of the possibility to bring CCL in the context of China. We begin by describing what we mean by CCL.

\subsection{What is climate change litigation?}

Trying to give CCL a clear definition represents a challenging task, as it concerns a relatively new worldwide judicial phenomenon which encompasses a broad range of legal forms and never stops evolving. Hilson (2010) defined CCL as cases "with some sort of deliberate framing in climate change terms" and in which "climate change argument is explicitly presented as part of the claimant's or defendant's case". Following this narrow definition, Markell and Ruhl (2012) proposes a widely accepted definition of CCL: "[a]ny piece of federal, state, tribal, or local administrative or judicial litigation in which 
the tribunal decisions directly and expressly raise an issue of fact or law regarding the substance or policy of climate change causes and impacts." Compared to the narrow definition proposed earlier, Peel and Osofsky (2015) drew a rather broad sphere of climate litigation by including "litigation with climate change as central issue" (core cases with "deliberate framing of the arguments or judgement in climate change terms"), "litigation with climate change as peripheral issue", "litigation with climate change as one motivation but not raised as an issue" and "litigation with no specific climate change framing but implications for mitigation or adaptation" (e.g. fracking cases). In The Status of Climate Change Litigation: A Global Review, UNEP (2017) follows the middle path by defining CCL as "cases brought before administrative, judicial and other investigatory bodies that raise issues of law or fact regarding the science of climate change and climate change mitigation and adaptation efforts", thus being flexible enough to include cases addressing "in direct or meaningful fashion the laws, policies, or actions that compel, support, or facilitate climate mitigation or adaptation", without "directly" or "expressly" mentioning "climate change" or other relevant keywords.

As this article is concerned with legal thresholds for CCL in both global and Chinese context, our focus has been on cases that raise climate-specific arguments. The narrow definition of CCL is followed.

\subsection{General legal preconditions for CCL in a global perspective}

According to the UN report The Status of Climate Change Litigation, till 2017, "climate change cases had been filed in only 24 countries ( 25 if one counts the European Union), with 654 cases filed in the United States and over 230 cases filed in all other countries combined." In other words, about $80 \%$ of the total number of CCL have taken place in the US and there are still a lot of states with no such CCL experience. Yet the reasons that explain this absence of CCL in the majority of countries remains obscure. Some thorny questions should first be answered, namely, who is entitled to file the suit before the court? Who is to be blamed for having caused climate change? How does one prove the damage as well as the causal link between the damage and the emission? In an effort to find an answer to these questions, two pathways have been followed, i.e. the civil CCL against the polluters and the administrative CCL against the government.

In all successful global CCL cases of both pathways, six legal preconditions are usually satisfied. It is noteworthy that these preconditions vary according to whether the cases were administrative or civil (See Tab. 2):

a. Procedural laws allowing PIL which enables the public interest in climate change to be represented before the courts; or

b. People's climate or environmental rights are recognized as fundamental rights; or

c. Government climate duties to reduce the emission of GHGs are specified in laws or policies, especially in the case of climate change administrative actions against the government; or

d. Same or similar regulatory framework for GHGs and air pollutants; or

e. Direct application of international law; or

f. A certain degree of judicial activism which guarantees the active role of climate change public policy in judicial decisions.

As an initial matter, one of the major impediments to the judicial protection of collective rights related to the climate change is the "gatekeeper doctrines" falling under "justiciability", among which the law of standing considers whether the plaintiff is the proper person to assert the claim. Many courts require plaintiffs to have a "direct interest", in other words, to show that they have suffered or will suffer an injury that is caused by the defendant's allegedly unlawful behavior. As the global climate represents a common good, this "direct interest" threshold would represent a major barrier for CCL. Therefore, in order to partially clear the important obstacle of "standing" problem for CCL, specific legal arrangements for PILs are usually indispensable.

Once a matter is determined to be justiciable and a court has jurisdiction to hear the matter, the case turns to the substantive merits. The civil and administrative CCLs are based on different approaches. In the case of administrative CCL, judicial decisions usually grounded their instructions on a rights-based analysis. It usually concerns urging governments to fulfill their international commitments or challenging the issuance of licenses for certain climate related projects. Thus, three preconditions should usually be met. First, legislation or policies have specified the duty of the government to reduce the emission of GHGs. Second, people's environmental rights are recognized as fundamental rights according to the national legislation. Or third, the adoption of monism which allows the direct application of international law in internal affairs and certain degree of judicial activism could help achieve a breakthrough similar to what has happened in the United States. In the case of civil CCL, as the plaintiff usually bases its argument on the damages caused by the climate change, the most difficult yet inevitable task is to prove the causality between the claimed injuries and the particular emission. In that case, two legal conditions are most relevant. First, one possible solution is to urge the environmental administrative authority to include the GHGs into the list of pollutants and regulate them under the same legal framework, or, second, the successful establishment of causal relationship between climate change-related injuries and particular emission through other possible pathways.

\section{Evaluation of viable options of future CLLs in China}

Based on the analysis above, there are five possible patterns for CCL in China. In the case of civil CCL against the polluters, the plaintiff could be either NGOs, prosecutors or local governments. Another important variables is the motivation of potential plaintiffs in bringing CCL. Based on the evaluation of both the 
preparation of legal preconditions and the motivation of potential plaintiffs, the probabilities of all the four potential patterns will be carefully evaluated and compared in the following paragraphs (Tab. 5).

\subsection{Evaluation of legal preconditions for Chinese CCL}

\subsubsection{Evaluation of legal preconditions for administrative CCL in China: public prosecutors vs. governments (Pattern A)}

According to Chinese law, with respect to administrative cases, the plaintiff can be either prosecutors or NGOs. However, as the standing of NGOs in the administrative CCL is neither explicitly stated in Chinese legislation, nor has such litigation ever been recorded in judicial practices especially after the modification of APL, the second pattern (ENGO vs. Government) exists only in theory for now. In the case of plain administrative actions (nonpublic interest litigations) brought by the citizen, as it is impossible to prove the "direct interests" of a particular individual affected by actionable "specific administrative acts" concerning response to climate change, this pathway turns out to be a dead end in China.

As the governmental legal duties to reduce the GHG emissions have not yet been specified in the law, it would be difficult for Chinese public prosecutors to bring a lawsuit against the government for their acts of nonfeasance or misfeasance in the field of climate change. A potential breakthrough lies in the influence of environmental policies on judicial decisions. Although governments do not have legal duties to reduce or limit GHGs emission, their relevant duties are however explicitly stated in the climate policies. As discussed above, if there is a way to overcome the obstacle of "abstract administrative act", it is then possible for legitimate plaintiff to bring administrative CCL. As a matter of fact, under certain conditions, the implementation of governmental policies can also be deemed as "specific administrative act" which is actionable. Especially under the condition that GHGs are regulated under the same framework of other air pollutants, the government who failed to appropriately regulate the emission of GHGs could then be held accountable for their "nonfeasance".

\subsubsection{Evaluation of legal preconditions for civil CCL in China: patterns $B, C$ and $D$}

Compared to the administrative CCL, in China, the types of potential plaintiffs for civil CCL are much more diverse, leading to three potential patterns: Local governments vs. Industries (Pattern B), Prosecutors vs. Industries (Pattern C) and NGOs vs. Industries (Pattern D).

Civil CCL could be brought by local governments, NGOs or prosecutors. Considering that the legal thresholds for judicial proceedings concerning environmental PIL and tort-based environmental litigation are different, as theoretically the relief of causal proof burden and the only apply to environmental PIL cases, it is above all necessary to clarify the nature of these litigations. Pattern $\mathrm{C}$ and Pattern D concern PIL, the standings of NGOs and prosecutors are explicitly recognized by law. However, it is still quite controversial whether Pattern B could also be regarded as PIL. Some argues that the standing of the local governments derives from the environmental administrative competence of the government, governments bring the law suit on behalf of the public environmental interest, in that case, Pattern B could also fall under the PIL. Yet, it is generally believed that, the standing of local governments could be justified as they represent the owner of the natural resources (the atmosphere in the case of CCL). Therefore, local governments initiate a litigation as a tort claimant, the CCL brought by local governments is thus tort-based civil litigation.

Since it is difficult to claim that damages are caused by a particular emission of GHGs, all the civil CCL Patterns will face important barriers of causal proof. However, as pattern $\mathrm{C}$ and $\mathrm{D}$ both concern PIL, then the standing problem is solved, and, compared to the Pattern B, the proof burden for causation is also relieved. Moreover, both pattern $\mathrm{C}$ and $\mathrm{D}$ have already been adopted by recently emerging PILs on air pollution in Chinese courts, which could serve as a potential foundation for future CCL. So, patterns $\mathrm{C}$ and $\mathrm{D}$ represent particularly promising models for future Chinese CCLs.

\subsection{Evaluation of motivation of potential plaintiffs}

It is worth pointing out that the aforementioned legal conditions mentioned may be necessary, but as of yet are insufficient for the emergence of Chinese CCL. Even with all the necessary and appropriate legal tool-kits, many countries have not seen yet their first CCL. What eventually triggers the action is the motivation of potential plaintiffs. The motivation element is in a sense not just necessary, but may even be a sufficient precondition for the emergence of CCL.

A comparison between France and China illustrate the importance of motives. Both France and China are civil law countries, where judges follow codified statutes instead of precedents and both countries have similar legal frameworks that permit PIL, yet the climate related duties of the government are not specified in laws. Therefore, not a single CCL has ever been filed in France before 2018. What at last triggered the first litigation was the motivation of the local government. As the host State for the Paris Agreement, the intention of the municipal government to promote this multilateral agreement is strong. In February 2018, the City of Paris announced its intention to sue industries who burn fossil fuel for having caused the intensification of climate events, in which the City considers itself victim.

\subsubsection{Local governments}

Does the Chinese government have similar motivation? The answer is not that obvious. In China, where the government has overwhelming power over the judicial 
and legislative branches, governmental motives are in fact the most important precondition for the emergence of CCL. The Chinese central government, having promised to peak its emission of GHGs by 2030, is currently pursuing a lowcarbon path of development with great dedication and determination. However, since the most urgent task for China is to promote the low-carbon economy; the climate change which could merely serve as an argument for such national commitment, representing yet a far indirect cause. Moreover, even if the motivation of the central government is expectable, when it comes to the local governments, the answer is uncertain again. As the main sources of $\mathrm{CO}_{2}$ emissions are large companies in fields such as petrochemical and automobile industries, which constitute also major sources of local tax revenues, the local government may not be as enthusiastic as the central government in reducing $\mathrm{CO}_{2}$ emissions.

As a matter of fact, ever since the pilot project in 2015, local government have only initiated 27 proceedings. That is mainly because that the role of local government as the plaintiff in civil lawsuit may contradict its role as supervisor and law-executor. Moreover, the difficult coordination of tort claims initiated by local government and PILs brought by prosecutors and NGOs also keep the government from acting more proactively.

\subsubsection{Public Prosecutors}

In the case of the second potential plaintiff, the Chinese public prosecutors, who have seen their competencies regarding matters of anti-corruption investigation being transferred to the newly created Supervision Committee, are highly motivated to bring PILs to improve their presence. Under the framework of the pilot program mentioned above, the number of filed cases soared from 12 at the very beginning to 495 at the end of 2016, including 57 civil EPILs, 437 administrative EPILs and 1 administrative incidental civil EPILs. Therefore, the motivation of Chinese public prosecutors in bringing CCL is obviously higher than the local governments. Yet, they could still act under the pressure of local governments, and may thus be less motivated in challenging major emitters.

\subsubsection{Environmental NGOs}

At last, the most highly motivated potential plaintiff is the environmental NGOs. Whether to genuinely protect the public interest in climate change, or due to an impulse to enhance their reputation, NGOs are more than willing to bring the first CCL in China. The first Chinese PIL case on air pollution, for example, was brought by an NGO. Chinese NGOs have already successfully brought a certain amount of PIL cases on air pollution, which serves as an important source of expertise for future potential CCL. Furthermore, there is one important legal precondition underway: with the creation of the new MEE which is responsible for the both $\mathrm{CO}_{2}$ and other air pollutants emission control, the administrative governance over $\mathrm{CO}_{2}$ and other air pollutants may be coordinated one day. Once the GHGs make the list of pollutants, Chinese ENGOs would spare no effort to bring civil CCL holding the polluters responsible for their excessive emission of $\mathrm{CO}_{2}$, similar to what they have already done in the fight against air pollution. Therefore, NGOs are most likely to be the plaintiff in the future CCL, judging by their motivation to act.

\subsection{Most promising pattern for CCL in China: Pattern D}

Based on the analysis proposed above, China is increasingly legally prepared for the emergence of CCL. In this case, which pattern would have the best chance to be accepted by Chinese judges in the future? According to this research, as demonstrated in Table 6 , the most promising pattern of CLL in China is probably the civil CCL pattern initiated by NGOs (Pattern D).

Judging by the preparation of legal preconditions, the civil CCL (PIL) brought by local governments (Pattern B), public prosecutors (Pattern C) or NGOs (Pattern D) are quite similar. Yet, as both prosecutors and NGOs have acquired experience in PILs on air pollution, some initial legal barriers, including the standing and the causal proof have already been challenged by both potential plaintiffs. Therefore, Patterns C and Pattern D seem to enjoy more favorable conditions than Pattern B which is still evolving and it is thus difficult to predict how it would proceed in future. Compared to civil CCL, the administrative CCL brought by the public prosecutors is less well prepared. Considering that the government's specific duties to respond to the climate change are absent in current laws, its duties stated in policy documents are not actionable and the $\mathrm{CO}_{2}$ has not been regulated under the same framework of air pollutants, the administrative CCL seems to be the most legally unfavorable pattern among four.

With respect to the motivation of potential plaintiffs, the difference is much more significant. In order to provide a possible answer to a series of thorny questions presented first in front of the judges, a spirit of creativity and perseverance of the claimant is badly needed. Although the local governments and the public prosecutors are both somewhat motivated, they are also more easily to get frustrated or intimidated by failures or even the risk of failures. To the contrary, the public interest lawyer would even in some situations risk an unfavorable decision for a chance. In that case, more participation by civil society, especially the environmental NGOs which is one of the most active and creative element, would probably break the deadlock and offer a different pathway towards CCL in China.

To conclude, judging from the strongest motivation of the NGOs as well as the preparation of relevant legal preconditions, according to this study, the Pattern D would then be the most likely and viable pattern for future Chinese CCL.

\section{Conclusion}

China, as the biggest $\mathrm{CO}_{2}$ emitter in the world, has long been accustomed to the traditional top-down and command-and-control environmental administrative approach which has proven to be highly problematic. The 
reasons are multifold, among which the institutional dysfunction prevails. In vertical dimension, the enforcement of environmental legislations and policies is impeded by the local governments out of economic concerns. In the horizontal perspective, the environmental competences are scattered across various government agencies and ministries. Thus, multiple government ministries and municipal authorities are involved in the management of GHGs. Once again, the department representing the economic interests would probably prevail over the environmental department in the control of $\mathrm{CO}_{2}$ emissions. Although important intuitional reforms have been undertaken, the conflict between the climate good and the economic development remains.

Therefore, the judicial approach could provide another mechanism urging the government or the industry to reconsider climate related public interest and accelerate the changes in the development pattern and in the industrial restructuring. Yet, thus far China has not seen a single CCL in its strict sense. For the civil CCL, as $\mathrm{CO}_{2}$ has not made the list of pollutants, climate related damages are hard to prove. In the case of administrative CCL, lack of basis for people's environmental rights and nonactionable climate change-related duties of the government stand in the way. On the other hand, institutional barriers are important. The fragmentation of air related competence, the problematic local enforcement of climate policy as well as the limited judicial activism further complicate the problem. However, it does not necessarily mean that CCL will not happen in China, since some normative and institutional preconditions have already been prepared or are underway. Based on the evaluation of the relevant legal preconditions as well as the institutional arrangements behind it, four patterns of the future CCL may appear in China: civil actions involving local governments, prosecutors or ENGOs, and the administrative actions with public prosecutors against the administrative authorities. Considering the preparation of the legal preconditions and the motivation of the plaintiffs, the article concludes that the most promising pattern of the potential Chinese CCL in the future would be civil actions brought by the ENGOs holding the polluters accountable for causing damages to the public interests in climate change.

Tab. 1 Legal preconditions for civil and administrative CCL

\begin{tabular}{|l|l|l|l|}
\hline CCL & Causes & Basic question & Legal Preconditions \\
\hline $\begin{array}{l}\text { Civil } \\
\text { litigation }\end{array}$ & $\begin{array}{l}\text { Environmen-tal } \\
\text { tort }\end{array}$ & $\begin{array}{l}\text { Causality to be } \\
\text { proved }\end{array}$ & $\begin{array}{l}\text { 1. PIL allowed by law except in the case of private interest } \\
\text { litigation; } \\
\text { 2. Successful establishment of the causality between climate } \\
\text { change-related injuries and a particular emission; } \\
\text { 3. Or GHGs are defined as air pollutants; }\end{array}$ \\
\hline $\begin{array}{l}\text { Administ- } \\
\text { rative } \\
\text { litigation }\end{array}$ & $\begin{array}{l}\text { Acts of } \\
\text { nisfeasance or }\end{array}$ & $\begin{array}{l}\text { 1. PIL allowed by law; } \\
\text { Environmental Government climate duties are specified in laws or policies; } \\
\text { rights-based }\end{array}$ & $\begin{array}{l}\text { 3. PHGs are defined as air pollutants; } \\
\text { fundamental rights; } \\
\text { 4. Adoption of monism (direct application of international } \\
\text { law). }\end{array}$ \\
\hline
\end{tabular}

Tab. 2 Evaluation of the preparation of legal preconditions for Chinese CCL patterns

\begin{tabular}{|c|c|c|c|c|c|c|}
\hline & \multicolumn{3}{|l|}{ Civil CCL. } & \multicolumn{3}{|c|}{ Administrative CCL } \\
\hline Defendants & \multicolumn{3}{|l|}{ Industries } & \multicolumn{3}{|c|}{ Government/Governmental Agencies } \\
\hline $\begin{array}{l}\text { Potential } \\
\text { Plaintiffs }\end{array}$ & $\begin{array}{l}\text { Local } \\
\text { governments } \\
\text { (B) }\end{array}$ & $\begin{array}{l}\text { Prosecutors } \\
\text { (C) }\end{array}$ & $\begin{array}{l}\text { NGOs } \\
\text { (D) }\end{array}$ & $\begin{array}{l}\text { Prosecutors } \\
\text { (A) }\end{array}$ & $\begin{array}{l}\text { ENGOs (Exist } \\
\text { only in theory) }\end{array}$ & $\begin{array}{l}\text { Citizens/Indiv } \\
\text { iduals (N/A) }\end{array}$ \\
\hline \multirow[b]{2}{*}{$\begin{array}{l}\text { Evaluation of } \\
\text { existing legal } \\
\text { conditions }\end{array}$} & $\begin{array}{l}\text { Standing (as the } \\
\text { owner of natural } \\
\text { resources) in } \\
\text { tort-based } \\
\text { environmental } \\
\text { actions (P); }\end{array}$ & \multicolumn{2}{|c|}{$\begin{array}{l}\text { Standing in civil PIL } \\
\text { allowed by law }(\mathrm{P}) \text {; }\end{array}$} & $\begin{array}{l}\text { Standing in } \\
\text { administrative } \\
\text { PIL (P); }\end{array}$ & $\begin{array}{l}\text { Standing in } \\
\text { administrative PIL } \\
(\mathrm{NY}) \text {; }\end{array}$ & $\begin{array}{l}\text { Standing in } \\
\text { plain } \\
\text { administrative } \\
\text { actions }(\mathrm{P})\end{array}$ \\
\hline & \multicolumn{3}{|c|}{$\begin{array}{l}\text { And establishment of "relatedness" between } \\
\text { climate related damage or "risk of damage" } \\
\text { and particular emission (P); Shift of the } \\
\text { burden of proof }(\mathrm{P}) \text {; and GHGs regulated as } \\
\text { pollutants }(\mathrm{NY})\end{array}$} & \multicolumn{2}{|c|}{$\begin{array}{l}\text { Government's actionable duties to } \\
\text { respond to the climate change } \\
\text { specified in laws or Policies } \\
\text { (NY);Or People's Environmental } \\
\text { rights recognized by law (NY);Or } \\
\text { GHGs regulated as pollutants (NY); } \\
\text { Or direct application of international } \\
\text { law (N); }\end{array}$} & $\begin{array}{l}\text { And Direct } \\
\text { interests } \\
\text { affected by } \\
\text { actionable } \\
\text { administrative } \\
\text { acts }(\mathrm{N})\end{array}$ \\
\hline
\end{tabular}

P: Prepared; NY: Not yet (Might be prepared in future); N: No (Not a chance in the near future). 
Tab.3 Climate related legislations

\begin{tabular}{|c|c|c|}
\hline Legislations & Effective date & Government duties \\
\hline Forest Law & $1 / 1 / 1985$ & $\begin{array}{l}\text { To protect, nurture, and rationally use forest resources, } \\
\text { speed up greening of the land. }\end{array}$ \\
\hline Meteorology law & $1 / 1 / 2000$ & Rationally develop, utilize and protect climate resources. \\
\hline $\begin{array}{l}\text { Law of the PRC on Desert } \\
\text { Prevention and } \\
\text { Transformation }\end{array}$ & $1 / 1 / 2002$ & $\begin{array}{l}\text { Prevention of desertification and control of decertified land. } \\
\text { Mitigating the negative impact of climate change on land. }\end{array}$ \\
\hline $\begin{array}{l}\text { Cleaner Production } \\
\text { Promotion Law }\end{array}$ & $1 / 1 / 2003$ & $\begin{array}{l}\text { To promote cleaner production, improve the efficiency of } \\
\text { resource use, and reduce and avoid the production of } \\
\text { pollutants. }\end{array}$ \\
\hline Renewable Energy Law & $1 / 1 / 2006$ & Improve energy structure and ensure energy security. \\
\hline Energy Conservation Law & $28 / 10 / 2007$ & $\begin{array}{l}\text { To promote energy conservation in the whole society, } \\
\text { enhance energy utilization efficiency, protect and improve } \\
\text { environment. }\end{array}$ \\
\hline $\begin{array}{l}\text { Circular Economy } \\
\text { Promotion Law }\end{array}$ & $1 / 1 / 2009$ & $\begin{array}{l}\text { To promote the development of circular economy, improve } \\
\text { the efficiency of resource utilization. }\end{array}$ \\
\hline Grassland Law & $29 / 6 / 2013$ & $\begin{array}{l}\text { To conserve water resources, maintain soil and water, and } \\
\text { prevent wind and sand. }\end{array}$ \\
\hline $\begin{array}{l}\text { Environmental Protection } \\
\text { Law }\end{array}$ & $1 / 1 / 2015$ & $\begin{array}{l}\text { To strengthen the protection of the atmosphere, water, soil } \\
\text { and improve the corresponding investigation, monitoring, } \\
\text { assessment and repairing system. }\end{array}$ \\
\hline $\begin{array}{l}\text { Atmospheric Pollution } \\
\text { Prevention and Control } \\
\text { Law }\end{array}$ & $1 / 1 / 2016$ & $\begin{array}{l}\text { To prevent air pollution and control greenhouse gas } \\
\text { emissions. }\end{array}$ \\
\hline
\end{tabular}

Tab.4 Climate related policy documents

\begin{tabular}{|c|c|c|c|}
\hline Policy documents & $\begin{array}{l}\text { Promulgated } \\
\text { in }\end{array}$ & Promulgator & Government Duties \\
\hline Climate change resolution & 2009 & $\begin{array}{l}\text { China Development and } \\
\text { Reform Commission and } \\
\text { NPC Standing Committee } \\
\end{array}$ & Actively respond to climate change. \\
\hline $\begin{array}{l}\text { Notification on launching } \\
\text { a pilot project for a low- } \\
\text { carbon community }\end{array}$ & 2014 & $\begin{array}{l}\text { China Development and } \\
\text { Reform Commission }\end{array}$ & $\begin{array}{l}\text { Establish Low carbon life style and } \\
\text { low carbon construction }\end{array}$ \\
\hline $\begin{array}{l}\text { National Plan for Climate } \\
\text { Change (2014-2020) }\end{array}$ & 2014 & $\begin{array}{l}\text { China Development and } \\
\text { Reform Commission with } \\
\text { State Council } \\
\end{array}$ & $\begin{array}{l}\text { Mitigate and adapt to climate } \\
\text { change; build up a greener low } \\
\text { carbon development model. }\end{array}$ \\
\hline $\begin{array}{l}\text { Accelerating the } \\
\text { Advancement of } \\
\text { Ecological Civilization } \\
\text { Construction }\end{array}$ & 2015 & $\begin{array}{l}\text { CPC Central Committee } \\
\text { and State Council }\end{array}$ & Promote low carbon economy \\
\hline $\begin{array}{l}\text { The "Thirteenth Five- } \\
\text { Year Plan" of Ecological } \\
\text { Environmental Protection }\end{array}$ & 2016 & State Council & $\begin{array}{l}\text { Promote green economy; Strengthen } \\
\text { ecological protection. }\end{array}$ \\
\hline $\begin{array}{l}\text { Control of greenhouse gas } \\
\text { emissions }\end{array}$ & 2016 & State Council & $\begin{array}{l}\text { Promote energy restructuring and } \\
\text { low carbon economy. }\end{array}$ \\
\hline $\begin{array}{l}\text { Plan on forestry responds } \\
\text { to climate change }\end{array}$ & 2017 & $\begin{array}{l}\text { State Forestry } \\
\text { Administration }\end{array}$ & $\begin{array}{l}\text { Increase forest carbon sinks and } \\
\text { promote the carbon trade } \\
\text { construction. }\end{array}$ \\
\hline
\end{tabular}

Tab. 5 Evaluation of the preparation of legal preconditions for Chinese CCL patterns

\begin{tabular}{|c|c|c|c|c|c|c|}
\hline & \multicolumn{3}{|l|}{ Civil CCL. } & \multicolumn{3}{|c|}{ Administrative CCL } \\
\hline Defendants & \multicolumn{3}{|l|}{ Industries } & \multicolumn{3}{|c|}{ Government/Governmental Agencies } \\
\hline $\begin{array}{l}\text { Potential } \\
\text { Plaintiffs }\end{array}$ & $\begin{array}{l}\text { Local } \\
\text { governments } \\
\text { (B) }\end{array}$ & $\begin{array}{l}\text { Prosecutors } \\
\text { (C) }\end{array}$ & $\begin{array}{l}\text { NGOs } \\
\text { (D) }\end{array}$ & $\begin{array}{l}\text { Prosecutors } \\
\text { (A) }\end{array}$ & $\begin{array}{l}\text { ENGOs (Exist } \\
\text { only in theory) }\end{array}$ & $\begin{array}{l}\text { Citizens/Indiv } \\
\text { iduals (N/A) }\end{array}$ \\
\hline $\begin{array}{l}\text { Evaluation } \\
\text { of existing } \\
\text { legal } \\
\text { conditions }\end{array}$ & $\begin{array}{l}\text { Standing (as the } \\
\text { owner of natural } \\
\text { resources) in } \\
\text { tort-based }\end{array}$ & \multicolumn{2}{|c|}{$\begin{array}{l}\text { Standing in civil PIL } \\
\text { allowed by law (P); }\end{array}$} & $\begin{array}{l}\text { Standing in } \\
\text { administrative } \\
\text { PIL (P); }\end{array}$ & $\begin{array}{l}\text { Standing in } \\
\text { administrative PIL } \\
(\mathrm{NY}) \text {; }\end{array}$ & $\begin{array}{l}\text { Standing in } \\
\text { plain } \\
\text { administrative } \\
\text { actions }(\mathrm{P})\end{array}$ \\
\hline
\end{tabular}




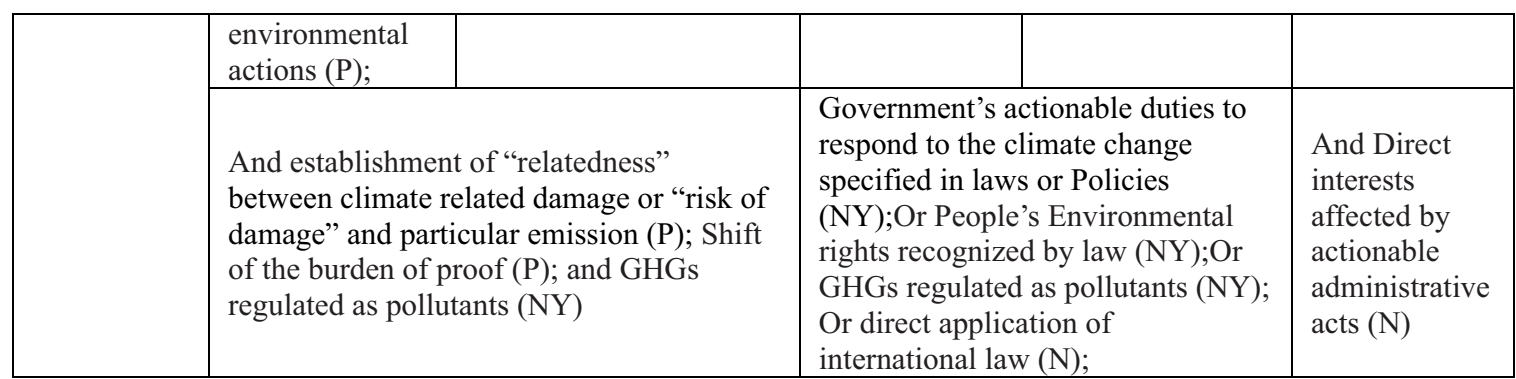

Tab. 6 Evaluation of probabilities of four potential patterns

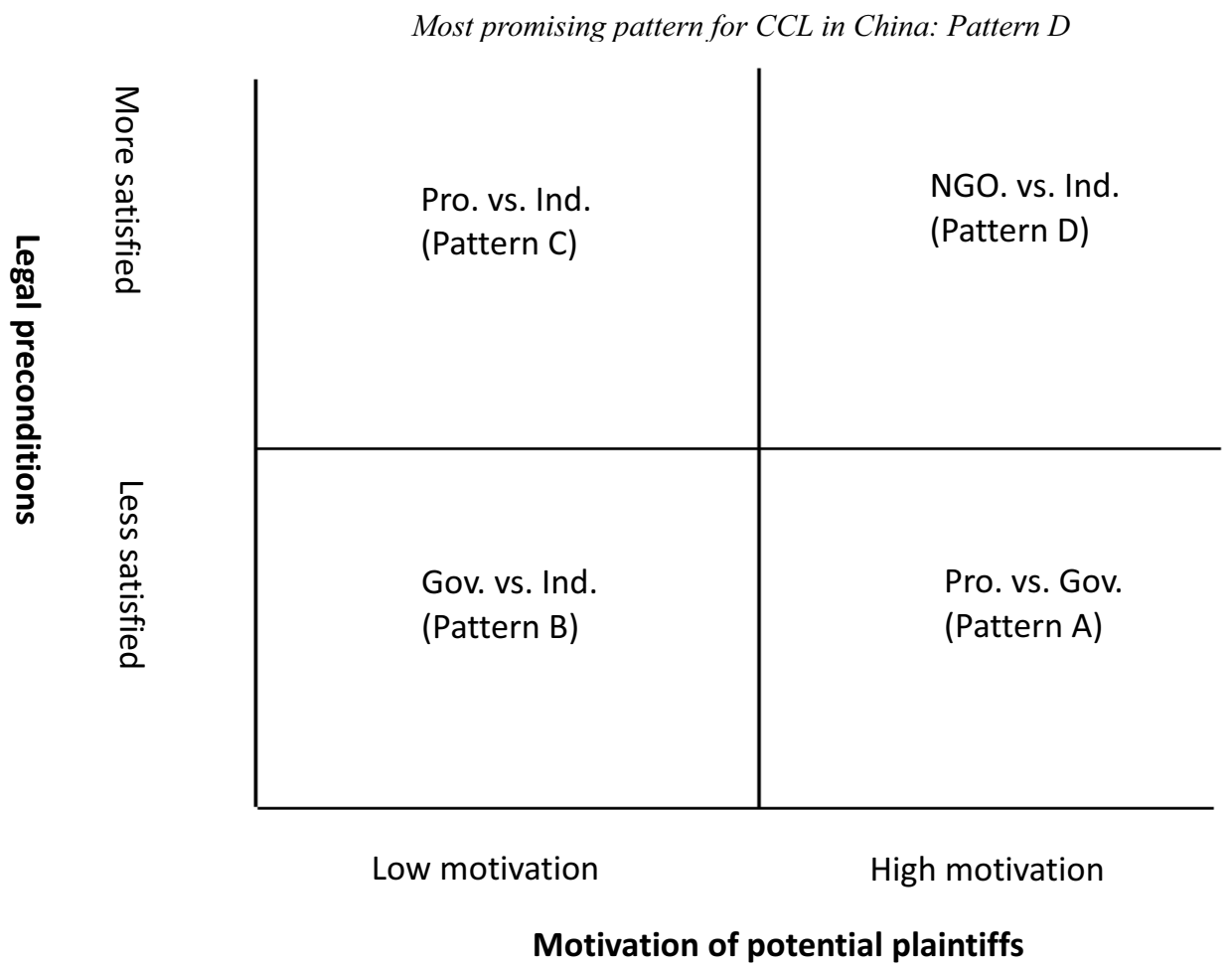

\section{References}

1. Zhang Feng. Construction of the Legal System of Environmental Public Interest Litigation by Individual Citizens in China [J]. Law Forum,2015,30(06):71-77.

2. Wang Mingyuan. On the Development Direction of Environmental Public Interest Litigation in China: Based on the Analysis of the Relationship between Executive Power and Judicial Power [J].Jurisprudence of China:,2016(01):49-68.

3. $\mathrm{Hu}$ Xuejun. Causality and Proof in Environmental Tort [J]. Chinese Law,2013(05):163-177.

4. Guo Hailan, Chen Demin.Analysis of the effect of environmental damage compensation on environmental protection [J].China Population, Resources and Environment,2018,28(03):86-94.

5. Zhu Jianyong, Chen Shili, Liu Liang. Research on the Linkage Mechanism of Eco-environmental Damage Compensation and Environmental Public Interest Litigation [A].National Procurators College, Law School of Renmin University of China.Deepening the Operation of Procuratorial Power under the
Background of Rule of Law Practice -- Proceedings of the Fourteenth National Senior Prosecutors Forum [C].National Procurators' College, Renmin University of China Law School: National Procurators' College,2018:12. 